\title{
ANNOTATIONS
}

\section{ORAL ADMINISTRATION OF BISTOVOL IN GENERAL PARALYSIS}

Bistovol (basic bismuth acetylamino-hydroxyphenyl arsonate) is a compound of bismuth and stovarsol (acetarsol sodium). The compound is obtainable in tablets for oral use.

According to Levaditi, and to Levaditi and Fournier, some of the bismuth appears in the urine after the oral administration of Bistovol ; hence it offers a convenient method of combining stovarsol and bismuth therapy without resource to injections.

Since July 1927 it has been the routine at this hospital to treat general paralysis with malaria, supplemented by the administration of pentavalent organic arsenicals. In 1936 oral stovarsol took the place of tryparsamide, and during the eight-year-period 1937-1944 the oral preparation of Bistovol has been used. The last-mentioned compound has been given initially in nearly every case for several alternate weeks prior to inoculation with malaria, the daily dosage being one tablet (4 grains) less than the patient's weight in stones (for example, 2 tablets 4 times a day on alternate weeks for a patient weighing 9 stone 5 pounds). The dose was reduced or omitted in the occasional cases in which dermatitis developed, and such patients were given ascorbic acid.

The optimal period for chemotherapy with Bistovol prior to the use of malaria therapy appeared to be about 3 months, since patients showed no further mental or physical improvement if this period were exceeded. Debilitated cases either died during this period or recovered sufficiently to tolerate 8 malarial rigors.

The clinical results attributable to Bistovol alone have been similar to those previously published with regard to stovarsol (Pakenham-Walsh and Rennie), but the cell counts in the cerebrospinal fluid were more rapidly reduced by the former. Unlike stovarsol, Bistovol has been well tolerated by the gastro-intestinal

TABLE 1.-GENERAL PARALYSIS OF THE INSANE - ADMISSIONS, RECOVERIES, AND DEATHS AT LANCASTER.

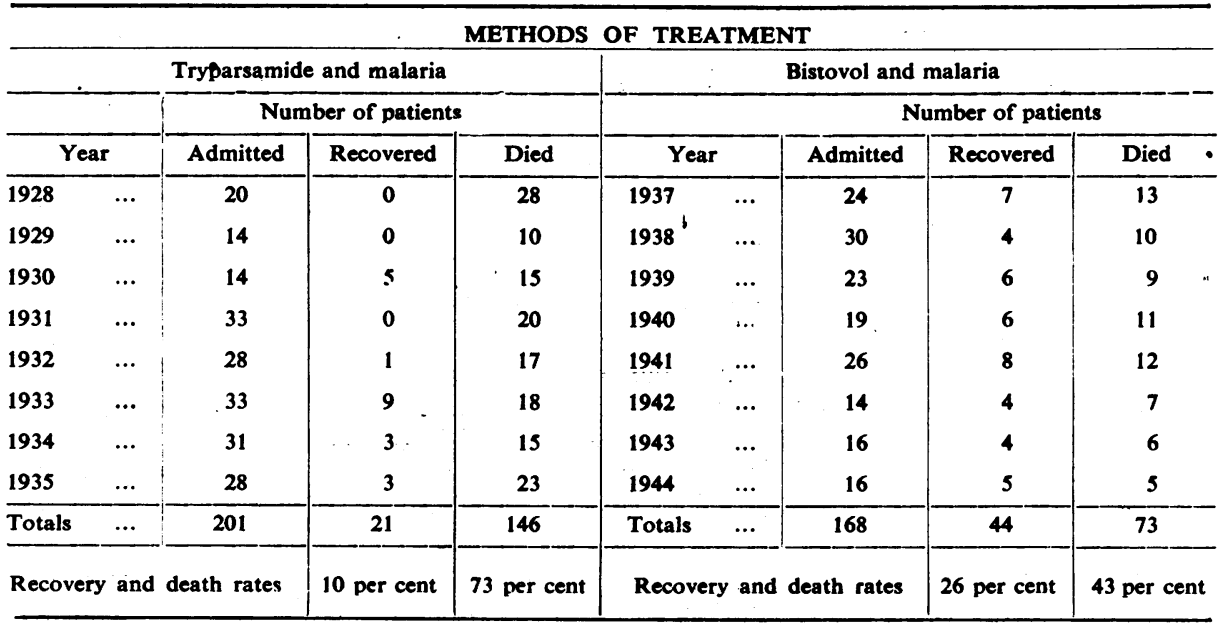

tract, provided that not more than 2 tablets are given simultaneously at intervals of at least 2 hours.

In Table 1, the eight-year period during which Bistovol was used at Lancaster in conjunction with malaria therapy is compared with another eight-year period during which malaria was supplemented by tryparsamide. Unfortunately a large number of patients in the tryparsamide group received malaria therapy initially, and many of these died before the chemotherapy had been given a 


\section{ANNOTATIONS}

chance to produce its effect. Hence the obvious improvement in the Bistovol group does not indicate any superiority of Bistovol over tryparsamide. On the other hand, if an inert substance had been given to the majority of patients for several weeks prior to inoculation, the delay would have been deleterious. The figures therefore suggest that Bistovol is therapeutically active when given by mouth.

- In Tables 2 and 3 an attempt has been made to study the relative values of Bistovol and tryparsamide by means of the serological changes which follow the

TABLE 2-EFFECT OF BISTOVOL ON THE PARETIC FORMULA

\begin{tabular}{|c|c|c|c|c|c|c|c|c|}
\hline \multicolumn{4}{|c|}{ BEFORE TREATMENT } & INTERVAL & \multicolumn{4}{|c|}{ AFTER TREATMENT } \\
\hline $\begin{array}{l}\text { W..R. } \\
\text { C.S.F. }\end{array}$ & $\begin{array}{c}\text { Protein } \\
\text { mg. \% }\end{array}$ & $\begin{array}{c}\text { Lange } \\
\text { reaction }\end{array}$ & $\begin{array}{c}\text { Cells } \\
\text { per c.mm. }\end{array}$ & $\begin{array}{l}\text { No. of } \\
\text { weeks }\end{array}$ & $\begin{array}{l}\text { W.R.R. } \\
\text { C.S.F. }\end{array}$ & $\begin{array}{c}\text { Protein } \\
\text { mg. } \%\end{array}$ & $\begin{array}{c}\text { Lange } \\
\text { reaction }\end{array}$ & \begin{tabular}{|c|} 
Cells \\
per c.mm
\end{tabular} \\
\hline++ & 55 & 5555433210 & 8 & 9 & - & 30 & 0113220000 & 3 \\
\hline+++ & 90 & 5554432100 & 210 & 9 & +++ & 60 & 5555554200 & 2 \\
\hline+++ & 40 & 5543100000 & 6 & 11 & $++\frac{1}{2}$ & 40 & 3454420000 & 2 \\
\hline$++t$ & 100 & 5555543210 & 14 & 12 & $+t+$ & 100 & 5544421000 & 3 \\
\hline+++ & 50 & 5555543100 & 20 & 13 & $++t$ & 45 & 0121100000 & 2 \\
\hline+++ & 80 & 5555543100 & 60 & 13 & ++ & 90 & 5554432100 & 7 \\
\hline$++t$ & 140 & 5555555420 & 18 & 13 & $+\frac{1}{2}$ & 60 & 1343310000 & 4 \\
\hline+++ & 85 & 5554433200 & 33 & 15 & +++ & 40 & 5443310000 & 4 \\
\hline+++ & 80 & 5553100000 & 24 & 16 & \pm & 40 & 5544210000 & 3 \\
\hline++1 & 70 & 5554210000 & 9 & 16 & +++ & 65 & 1123100000 & 3 \\
\hline+++ & 80 & 5555554310 & 209 & 16 & +++ & 30 & 5554310000 & 4 \\
\hline+++ & 160 & 5555555421 & 75 & 17 & ++1 & 80 & 4443321000 & 4 \\
\hline+++ & 80 & 5555543100 & 21 & 17 & +++ & 70 & 5554431000 & 5 \\
\hline+++ & 75 & 5555543000 & 36 & 17 & +++ & 50 & $5543100000^{\circ}$ & 2 \\
\hline++1 & 210 & 5555432100 & 38 & 20 & +1 & 70 & 1111110000 & 4 \\
\hline+++ & 140 & 5555542100 & 31 & 20 & $++\frac{1}{2}$ & 50 & 5555430000 & 4 \\
\hline+++ & 120 & 5554432000 & $55 \cdot$ & 22 & $++t$ & 60 & 5543211000 & 2 \\
\hline . $+t$ & 80 & 5555543200 & 20 & 24 & \pm & 45 & 0135420000 & 2 \\
\hline+++ & 100 & 5555554310 & 16 & 31 & ++1 & 40 & 2344320000 & 2 \\
\hline+++ & 120 & 5555555421 & 25 & 31 & +++ & 80 & 5444433100 & 3 \\
\hline
\end{tabular}

$\left.\begin{array}{l}\text { W.R } \\ \text { C.S.F. }\end{array}\right\}=$ Wassermann reaction of cerebrospinal fluid

administration of these compounds over approximately the same periods of time.

The serological results given in Table 2 have been recorded in 20 cases of general paralysis, in which each of the patients exhibited a typical paretic formula prior to the commencement of treatment. The second readings were taken 9-31 weeks after the first, Bistovol having been given exclusively during the interval.

Table 3 (after Tennent) shows the effect of 15-37 injections of 3 grammes of tryparsamide in 10 cases of general paralysis. As the injections were given weekly and the second puncture was made "at the end of each course of treatment", it is evident that the intervals approximate to those of Table 2.

\section{Comment on Tables 2 and 3}

The Wassermann test.-Although the same method of recording has not been used throughout, it is evident that more than half the number of cases in each group have shown a weakening after treatment.

The protein content.-After treatment the average is 57 milligrams per cent 
in Table 2 and 56 milligrams per cent in Table 3, despite the fact that the initial averages are 98 and 125 milligrams per cent respectively.

The Lange reaction.--Some of the curves, notably the last in each series, have remained resistant to treatment. This is not surprising, since Hinrichsen states in a review on tryparsamide that $100-150$ injections of tryparsamide may be required to produce changes in the colloidal gold curve. The first tube result was a "five" in 55 per cent of my cases after the administration of Bistovol

TABLE 3-EFFECT OF TRYPARSAMIDE ON THE PARETIC FORMULA

\begin{tabular}{|c|c|c|c|c|c|c|c|c|}
\hline \multicolumn{4}{|c|}{ BEFORE TREATMENT } & \multirow{2}{*}{$\frac{\begin{array}{c}\text { TREAT- } \\
\text { MENT }\end{array}}{\begin{array}{r}\text { No. of } \\
\text { Injections }\end{array}}$} & \multicolumn{4}{|c|}{ AFTER TREATMENT } \\
\hline $\begin{array}{l}\text { W.R. } \\
\text { C.S.F. }\end{array}$ & $\begin{array}{l}\text { Protein } \\
\text { mg. } \%\end{array}$ & $\begin{array}{c}\text { Lange } \\
\text { Reaction }\end{array}$ & $\begin{array}{c}\text { Cells } \\
\text { fer c.mm. }\end{array}$ & & $\begin{array}{l}\text { W.R. } \\
\text { C-S.F. }\end{array}$ & $\begin{array}{c}\text { Protein } \\
\mathbf{m g} . \%\end{array}$ & $\begin{array}{l}\text { Lange } \\
\text { reaction }\end{array}$ & $\begin{array}{c}\text { Cells } \\
\text { fer c.mm. }\end{array}$ \\
\hline$+40+$ & 100 & 5443210000 & 50 & 15 & $+20+$ & 35 & 0000000000 & 5 \\
\hline$+40+$ & 180 & 5555543210 & 100 & 16 & +40 & 80 & 4434222110 & 37 \\
\hline$+40+$ & 125 & 5555543211 & 50 & 21 & $+40+$ & 75 & 5555432110 & 10 \\
\hline$+40+$ & 125 & 5555554321 & 78 & 22 & +40 & 80 & 5544321000 & 40 \\
\hline$+8+$ & 125 & 5555543200 & 80 & 24 & $+8+$ & 45 & 2223331100 & 5 \\
\hline$+40+$ & 130 & 5555543210 & 50 & 24 & $+40+$ & 80 & 5553322100 & 28 \\
\hline$+40+$ & 125 & 5555543210 & 80 & 28 & +8 & 45 & 0011100000 & 5 \\
\hline$+20+$ & 50 & 5555543210 & 18 & 28 & +4 & $30:$ & 0000000000 & 5 \\
\hline$+40+$ & 200 & 5555543210 & 100 & 35 & $+4 t$ & 35 & 3332211000 & 4 \\
\hline$+20+$ & 90 & 5555554400 & 50 & 37 & $+3+$ & 55 & 5554321100 & 3 \\
\hline
\end{tabular}

$\begin{aligned} & \text { W.R. } \\ & \text { C.S.F. }\end{aligned}=$ Wassermann reaction of cerebrospinal fluid

and in 40 per cent of Tennent's cases after tryparsamide medication.

The cells.-The reduction in the cell count is more consistent in the Bistovol series.

\section{Conclusions}

(1) The introduction of oral Bistovol as an adjuvant to the malarial treatment of general paralysis has coincided with a favourable alteration in the statistical tables of this hospital.

(2) Oral Bistovol has been specially suitable for the "building up" of debilitated patients, who would otherwise have been unfit to undergo malarial treatment.

- (3) Oral Bistovol has an effect on the paretic formula comparable to that of tryparsamide. It produces a more rapid reduction in the cell count than does tryparsamide or stovarsol.

(4) From the point of view of ease of administration and relative absence of toxic effect, oral Bistovol is preferable to tryparsamide and stovarsol.

(5) Further research is required in order to decide whether or not the penicillin treatment of general paralysis, now in vogue (Goldman), will displace the former methods or be used in conjunction with them.

I wish to thank Dr. J. D. Silverston, Medical Superintendent of the hospital, for permission to publish this paper, and also Prof. H. B. Maitland for the reports on the Wassermann reactions.

Lancaster

\section{REFERENCES}

Goldman, D. (1945) J. Amer. med. Ass., 128, 274.

Hinrichsen, J. (1.939) J. vener. Dis. Inform:, 20; 293.

Levaditi, C. (1928) Brit. J. vener. Dis., 4, 25

- and Fournier, L. (1928) Lancet, 1, 692.

Pakenham-Walsh, R., and Rennie, A. T. (1937) Lancet, 1, 982.

Tennent, T. (1931) J. ment. Sci., 77, 86. 